\title{
Gambaran Pengetahuan, Sikap Dan Tindakan Penerapan Protokol Kesehatan Covid-19 Warga Di Wilayah Percontohan Program Rt Siaga Kota Surabaya
}

\author{
M uhammad Baharuddin Wisudawan Putra* ${ }^{1}, 0$ edojo Soedirham ${ }^{2}$ \\ ${ }^{12}$ Department of Health Promotion and Behavioral Science, Faculty of Public Health, \\ Universitas Airlangga, Indonesia
}

Author's Email Correspondence (*): m.baharuddin.wisudawan.p-2016@fkm.unair.ac.id Phone : +6282143124470

\begin{abstract}
ABSTRAK
COVID-19 telah ditetapkan sebagai Kedaruratan Kesehatan Masyarakat yang Meresahkan Dunia (KKMMD). Provinsi Jawa Timur dan Kota Surabaya merupakan salah satu daerahi dengan angka kasus terbanyak dan telah dikategorikan sebagai zona merah. Total kasus konfirmasi positif COVID-19 di Jawa Timur sebanyak 3.642 Kasus. Namun di Kota Surabaya ada sebanyak 1.975 Kasus. Hal tersebut dari penerapan protokol kesehatan COVID-19 di masyarakat yang dipengaruhi oleh pengetahuan, sikap dan tindakan dari masyarakat. Tujuan penelitian ini adalah untuk mengetahui gambaran pengetahuan, sikap dan tindakan penerapan protokol kesehatan COVID-19 warga di wilayah program RT Siaga Surabaya. Penelitian ini menggunakan data primer dengan kuesioner yang berasal dari Program RT Siaga Kota Surabaya. Jumlah sampel responden dalam penelitian ini adalah 70 responden. Data dianalisis secara univariat dengan menyajikan distribusi frekuensi variabel. Karakteristik responden sebagian besar di usia 31-40 tahun dan berjenis kelamin laki-laki. Sebanyak 69 responden $(99 \%)$ memiliki pengetahuan penerapan protokol kesehatan dalam kategori baik. Sebanyak 70 responden (100\%) memiliki pemahaman sikap penerapan protokol kesehatan kategori baik sedangkan yang memiliki tindakan penerapan protokol kesehatan dalam kategori baik sebanyak 68 responden (97\%). Pengetahuan, sikap dan tindakan warga di wilayah program RT Siaga Kota Surabaya sebagian besar menunjukkan kategori baik terhadap penerapan protokol kesehatan COVID-19.
\end{abstract}

Kata Kunci: COVID-19, Pengetahuan, Sikap, Tindakan

Published by:

Tadulako University

Address:

Jl.Soekarno Hatta KM 9. Kota Palu, Sulawesi Tengah, Indonesia.

Phone: +628114120202

Email: Preventif.fkmuntad@gmail.com
Article history :

Received :09 112020

Received in revised form : 10112020

Accepted : 11112020

Available online : 30062021 


\begin{abstract}
COVID-19 has been designated as a Public Health Emergency of International Concern (PHEIC). East Java Province and Surabaya City are among the regions with the highest numbers and have been categorized as the red zone. The total number of confirmed positive cases of COVID-19 in East Java was 3,642 cases. However, in the city of Surabaya there were 1,975 cases. This is from the implementation of the COVID-19 health protocol in the community which is built by knowledge, attitudes and behavior from the community. The purpose of this study is to describe the knowledge, attitudes and behavior of implementing the COVID-19 health protocol for residents in the RT Siaga Surabaya program area. This study used primary data with questioner from the RT Siaga Program in Surabaya City. The number of samples in this study were 70 respondents. The data were analyzed univariately by presenting the variable frequency distribution. Most of the respondents were 31-40 years old and male. A total of 69 respondents (99\%) had knowledge of health protocols in the good category. As many as 70 respondents (100\%) had the attitude of implementing the health protocol in the good category and 68 respondents (97\%) had the behavior of implementing the health protocol in the good category. Most of the knowledge, attitudes and behavior of residents in the RT Siaga City Surabaya program area showed good categories for the implementation of the COVID-19 health protocol.
\end{abstract}

Keywords: COVID-19, Knowledge, Attitude, And Practice

\title{
PENDAHULUAN
}

Coronavirus Disease (COVID-19) atau biasa disebut dengan COVID-19 merupakan sebuah penyakit yang diakibatkan virus dari kelompok Coronavirus. COVID-19 telah menyebar hampir ke seluruh belahan dunia dan terjadi peningkatan kasus akumulatif secara terus-menerus hingga saat ini(1). Pada tanggal 31 Desember 2019, Tiongkok melaporkan kasus pneumonia misterius yang tidak diketahui penyebabnya. Dalam 3 hari, pasien dengan kasus tersebut berjumlah 70 pasien dan terus bertambah hingga saat ini berjumlah ribuan kasus. Pada awalnya data epidemiologi menunjukkan $66 \%$ pasien berkaitan atau terpajan dengan satu pasar seafood atau live market di Wuhan, Provinsi Hubei Tiongkok. Sampel isolat dari pasien diteliti dengan hasil menunjukkan adanya infeksi coronavirus, jenis betacoronavirus tipe baru, diberi nama 2019 novel Coronavirus (2019-nCoV).

Pada tanggal 30 Januari 2020, WHO menetapkan COVID-19 sebagai Public Health Emergency of International Concern (PHEIC) atau Kedaruratan Kesehatan Masyarakat yang Meresahkan Dunia (KKMMD). Pada tanggal 12 Februari 2020, WHO resmi menetapkan penyakit novel coronavirus pada manusia ini dengan sebutan Coronavirus Disease (COVID19). COVID-19 disebabkan oleh SARS-COV2 yang termasuk dalam keluarga besar coronavirus yang sama dengan penyebab SARS pada tahun 2003, yang hanya berbeda jenis virusnya (2). COVID-19 juga memiliki penyebaran yang lebih luas dan cepat ke beberapa negara dibanding SARS. World Health Organization (WHO) telah menetapkan Corona Virus Disease 2019 (COVID-19) sebagai pandemi global tepatnya pada Rabu, 11 Maret 2020. 
Menurut data dari WHO, total kasus konfirmasi COVID-19 global per tanggal 14 Mei 2020 adalah 4.248.389 kasus dengan 294.046 kematian (CFR 6,9\%) di 215 negara terjangkit. Persebaran COVID-19 hingga tanggal 14 Mei 2020 telah menyebar ke semua provinsi di Indonesia dengan total 16.006 kasus konfirmasi COVID-19 dan toal 1.043 kematian (3). Terdapat tiga provinsi yang memiliki kasus positif tertinggi yaitu DKI Jakarta dengan 5.688 kasus, Jawa Timur dengan 1.863 kasus dan Jawa Barat dengan 1.565 kasus. Provinsi Jawa Timur menjadi salah satu yang memiliki jumlah kasus COVID-19 tertinggi per tanggal 15 Mei 2020 dengan total kasus konfirmasi positif COVID-19 sebanyak 3.642 Kasus. Sedangkan untuk total pasien dalam pegawasan (PDP) total sebanyak 5.628 kasus dan orang dalam pengawasan (ODP) sebanyak 23.635 Kasus (4). Salah satu Kota/Kabupaten dengan kasus tertinggi yaitu Kota Surabaya sebanyak 1.975 Kasus.

Berdasarkan Dinas Kesehatan Kota Surabaya (2020) bahwa tren perkembangan COVID-19 di Surabaya terus mengalami peningkatan. Sejak tanggal 1 April 2020 dengan total konfirmasi 41 Kasus, kemudian berselang 1 bulan pada tanggal 1 Mei meningkat menjadi 496 kasus dan per tanggal 25 Mei 2020 kasus melonjak menjadi 2095 kasus konfirmasi dengan 2.000 kasus pada warga Surabaya dan 95 kasus pada warga luar Surabaya. Sedangkan kumulatif konfirmasi positif yang meninggal, total berjumlah 171 kasus dengan rincian 108 kasus pada warga Surabaya dan 6 kasus pada warga luar Surabaya. Sehingga hal ini memperlihatkan jika kasus masih terus mengalami peningkatan dan dalam kurun waktu kurang dari satu bulan di Kota Surabaya.

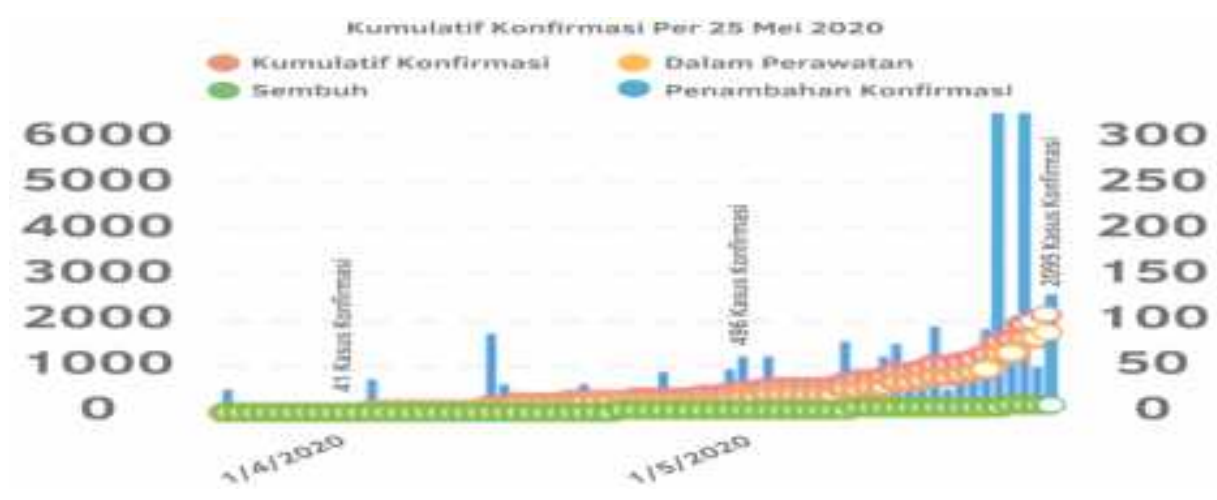

Gambar 1. Grafik Tren dan Kumulatif Konfirmasi Per 25 Mei di Surabaya (Sumber: Dinas Kesehatan Kota Surabaya, 2020 dari https://lawancovid-19.surabaya.go.id/)

Salah satu upaya yang dilakukan Pemerintah RI dengan terbentuknya Gugus Tugas Percepatan Penanganan COVID-19 juga telah menetapkan kejadian COVID-19 sebagai 
Bencana Nasional yang ditetapkan melalui SK BNPB No.9.A Tahun 2020 tentang Status Keadaan Tertentu Darurat Bencana Wabah Penyakit Akibat Virus Corona di Indonesia (2). Hal tersebut sekaligus dengan dikeluarkan keputusan untuk penetapan protokol kesehatan pada masyarakat Indonesia terutama Kota Surabaya. Kemudian melihat realita, semakin tingginya angka kasus di Jawa Timur, Pemerintah Provinsi Jawa Timur mencanangkan untuk segara diberlakukan Pembatasan Sosial Berskala Besar (PSBB). Salah satu upaya oleh Pemerintah Kota Surabaya berdasarkan informasi Dinas Kesehatan Kota Surabaya dengan pemantauan penerapan protokol kesehatan di masyarakat, pelaksanaan tracing, edukasi kesehatan, pemberian bantuan kepada warga dan lain sebagainya. Proses pelaksanaan upaya pencegahan dan penanganan COVID-19 tidak hanya dilakukan oleh pemerintah atau apparat setempat. Namun peran masyarakat dalam penanggulangan COVID-19 juga sangat diperlukan terutama dalam hal kedisiplinan penerapan protokol kesehatan COVID-19 di lingkungan setempat. Penerapan protokol kesehatan COVID-19 di masyarakat dipengaruhi oleh pengetahuan sikap dan tindakan dari masyarakat itu sendiri (6). Pengetahuan masyarakat tentang COVID-19 didapatkan dari edukasi pemerintah melalui media online maupun offline oleh perangkat wilayah setempat.

Pemberian edukasi oleh pemerintah yakni terkait pencegahan penularan, bahaya serta berbagai macam penanggulangan COVID-19. Namun, upaya pemberian edukasi masih mengalami berbagai macam kendala, salah satunya akses yang lebih banyak hanya melalui media online, serta sangat banyak juga edukasi yang salah atau HOAX yang tersebar di masyarakat terkait COVID-19 (7). Hal tersebut mengakibatkan penerapan protokol kesehatan COVID-19 masih rendah dilaksanakan oleh masyarakat, seperti penggunaan masker yang belum diterapkan, melakukan cuci tangan menggunakan sabun serta air mengalir yang belum dilakukan, adanya stigma yang kurang tepat pada kasus konfirmasi COVID-19 di masyarakat dan lain sebagainya. Pengetahuan dan tindakan yang nyata dari masyarakat terkait PHBS akan mampu membantu menurunkan jumlah kasus COVID-19, sehingga masa pandemi COVID-19 dapat berakhir dengan cepat (7). Maka dari itu, penelitian ini bertujuan untuk mengetahui terkait gambaran pengetahuan, sikap dan tindakan penerapan protokol kesehatan COVID-19 warga di wilayah program RT Siaga Kota Surabaya. Manfaat penelitian adalah sebagai dapat dijadikan dasar dalam menyusun berbagai program oleh pemerintah Kota Surabaya khususnya di wilayah Program RT Siaga sehingga terbebas dari pandemi COVID19. 


\section{METODE}

Peneliltian ini merupakan penelitian deskriptif. Sampel dipilih secara acak menggunakan metode purposive sampling. Desain penelitian ini dilakukan dengan pemberian post-test setelah diberikannya perlakuan. Jumlah sampel responden dalam penelitian ini adalah 70 responden yang berasal dari warga di Wilayah Program RT Siaga Kota Surabaya. Terdapat 4 wilayah percontohan program RT Siaga Kota Surabaya yaitu RT 01 RW 09 Kelurahan Jepara, RT 03 RW 03 Kelurahan Kejawan Putih Tambak, RT 01 RW 09 Kelurahan Pacar Keling dan RT 02 RW 04 Kelurahan Mojo. Data dianalisis secara univariat dengan menyajikan distribusi frekuensi variabel. Variabel dalam penelitian ini yaitu pengetahuan, sikap dan tindakan penerapan protokol kesehatan COVID-19 warga di wilayah program RT Siaga Kota Surabaya.

\section{HASIL}

\section{Distribusi Responden Berdasarkan Pengetahuan Penerapan Protokol Kesehatan COVID-19}

Variabel pengetahuan penerapan protokol kesehatan dengan jumlah responden sebanyak 70 responden. Terdapat 2 kategori dari pertanyaan mengenai variabel pengetahuan penerapan protokol kesehatan, yaitu: baik dan buruk. Distribusi frekuensi variabel pengetahuan penerapan protokol kesehatan ditampilkan dalam tabel 1 .

Tabel 1.

Distribusi Frekuensi Variabel Pengetahuan Penerapan Protokol Kesehatan COVID-19 di Wilayah Percontohan Program RT Siaga Kota Surabaya Tahun 2020

\begin{tabular}{ccc}
\hline Pengetahuan & n & \% \\
\hline Baik & 69 & $99 \%$ \\
Buruk & 1 & $1 \%$ \\
\hline Total & $\mathbf{7 0}$ & $\mathbf{1 0 0 , 0}$
\end{tabular}

Sumber: Data RT Siaga Satuan Tugas Covid-19 Pemerintah Provinsi Jawa Timur, 2020

Tabel 1 menunjukkan bahwa terdapat mayoritas responden telah memiliki pengetahuan yang baik dalam penerapan protokol kesehatan sebanyak 69 responden (99\%) dan yang memiliki pengetahuan buruk terkait pengetahuan penerapan protokol kesehatan hanya 1 responden $(1 \%)$. 
Variabel sikap penerapan protokol kesehatan dengan jumlah responden sebanyak 70 responden.Terdapat 2 kategori dari pertanyaan mengenai variabel sikap penerapan protokol kesehatan, antara lain: baik dan buruk. Distribusi frekuensi variabel sikap penerapan protokol kesehatan ditampilkan dalam tabel 2.

Tabel 2.

Distribusi Frekuensi Variabel Sikap Penerapan Protokol Kesehatan COVID-19 di Wilayah Percontohan Program RT Siaga Kota Surabaya Tahun 2020

\begin{tabular}{ccc}
\hline Sikap & n & \% \\
\hline Baik & 70 & $100 \%$ \\
Buruk & 0 & $0 \%$ \\
\hline Total & $\mathbf{7 0}$ & $\mathbf{1 0 0 , 0}$
\end{tabular}

Sumber: Data RT Siaga Satuan Tugas Covid-19 Pemerintah Provinsi Jawa Timur, 2020

Tabel 2 menunjukkan bahwa keseluruhan responden telah memiliki sikap yang baik dalam penerapan protokol kesehatan covid-19 sebanyak 70 responden.

\section{Distribusi Responden Berdasarkan Tindakan Penerapan Protokol Kesehatan COVID- 19}

Variabel tindakan penerapan protokol kesehatan dengan jumlah responden sebanyak 70 responden. Terdapat 2 kategori dari pertanyaan mengenai variabel tindakan penerapan protokol kesehatan, antara lain: baik dan buruk. Distribusi frekuensi variabel tindakan penerapan protokol kesehatan ditampilkan dalam tabel 3.

Tabel 3.

Distribusi Frekuensi Variabel Tindakan Penerapan Protokol Kesehatan COVID-19 di Wilayah Percontohan Program RT Siaga Kota Surabaya Tahun 2020

\begin{tabular}{ccc}
\hline Tindakan & $\mathbf{n}$ & \% \\
\hline Baik & 68 & $97 \%$ \\
Buruk & 2 & $3 \%$ \\
\hline Total & $\mathbf{7 0}$ & $\mathbf{1 0 0 , 0}$ \\
\hline
\end{tabular}

Sumber: Data RT Siaga Satuan Tugas Covid-19 Pemerintah Provinsi Jawa Timur, 2020

Tabel 3 menunjukkan bahwa sebanyak 68 responden (97\%) telah memiliki tindakan dengan kategori baik dalam penerapan protokol kesehatan covid-19 sedangkan hanya 2 responden $(3 \%)$ yang memiliki tindakan dengan kategori buruk dalam penerapan protokol kesehatan covid-19. 


\section{PEMBAHASAN}

\section{Pengetahuan Penerapan Protokol Kesehatan COVID-19}

Faktor pengetahuan atau kognitif merupakan salah satu domain yang penting untuk membentuk suatu perilaku dan perilaku tersebut menjadi dasar oleh pengetahuan akan bertahan lebih lama daripada tidak didasari pengetahuan(8).Terkait tingkat pengetahuan responden mengenai penerapan protokol kesehatan COVID-19 yang sudah tergolong baik, namun diketahui masih didapatkan ada responden yang belum memiliki pengetahuan yang baik. Pengetahuan responden yang sudah baik ini dapat terjadi karena beberapa faktor diantaranya umur, pendidikan, dan media massa. Selain itu, usia responden sebagian besar dalam penelitian ini termasuk dalam kategori dewasa sehingga akan mempengaruhi tingkat pemahaman dan pengetahuannya yang akan juga semakin tinggi.

Masyarakat yang mempunyai pengetahuan baik maka akan mempunyai sikap dan perilaku yang baik pula (6). Sejalan dengan teori dari Notoatmodjo (2012)(9) menjelaskan bahwa pengetahuan seseorang semakin baik karena bertambanya usia, sehingga semakin berkembang daya dan pola pikir seseorang. Selain itu, peran dari edukasi yang didapatkan dari berbagai sumber, seperti media cetak, media massa, media online serta dari kader atau perangkat setempat juga menjadi penunjang pengetahuan masyarakat setempat. Hal ini diperkuat dengan hasil dari montoring yang dilakukan, masyarakat mendapatkan edukasi secara langsung baik dari media yang dimiliki serta melalui kader kesehatan, satuan tugas atau perangkat setempat. Selama ini masyarakat mendapatkan edukasi dari berbagai sumber, seperti media cetak, media massa dan media online dari perangkat yang dimiliki, serta edukasi maupun informasi secara langsung dari keluarga, tetangga, kader, relawan, perangkat, tokoh masyarakat serta puskesmas juga menjadi penunjang pengetahuan masyarakat setempat. Hal ini juga sesuai dengan penelitian(10), yang menyatakan bahwa melalui peran perempuan sebagai ibu rumah tangga, kader, maupun tokoh masyarakat dapat ikut turut mensosialisasikan gerakan mematuhi kebijakan PSBB untuk mengurangi penyebaran Covid-19. Kemudian, menurut (11) yang menyatakan peran tokoh masyarakat dalam memberikan dukungan informatif tampak dalam upaya tokoh masyarakat menyebarluaskan informasi mengenai pandemi dan pencegahannya. Informasi terlebih dahulu disebarkan pada anggota keluarga, setelah itu disebarkan pada tetangga. Selain menyebarkan informasi, tokoh masyarakat juga mempromosikan perilaku hidup bersih dan sehat pada para warga desa yang meliputi, mensosialisasikan pembatasan sosial dan jaga jarak (social distancing dan physical distancing) pada warga desa; penggunaan masker saat 
keluar rumah; menghindari kerumunan, membersihkan rumah dengan disinfektan, berjemur diri, makan makanan sehat dan melakukan olah raga. Seseorang yang menerima suatu informasi tertentu, maka dia akan mampu menentukan dan mengambil suatu keputusan untuk bertindak. Dengan kata lain, saat individu mengetahui informasi tentang penerapan protokol kesehatan Covid-19, maka ia akan mampu untuk menentukan bagaimana dirinya harus berperilaku terhadap kejadian Covid-19 tersebut (12)

\section{Sikap Penerapan Protokol Kesehatan COVID-19}

Sikap secara nyata menunjukkan konotasi adanya kesesuaian reaksi terhadap stimulus tertentu yang dalam kehidupan sehari-hari merupakan reaksi yang bersifat emosional terhadap stimulus sosial (9). Sikap adalah suatu hubungan antara komponen kognitif, afektif, dan konatif dalam memahami, merasakan, dan berperilaku terhadap suatu objek (13). Sikap bukan berarti suatu perilaku atau tindakan melainkan kesiapan seseorang untuk bereaksi terhadap obyek-obyek tertentu (13).

Berdasarkan hasil yang telah diperoleh bahwa keseluruhan responden telah memiliki sikap penerapan protokol kesehatan COVID-19 yang tergolong baik. Hal tersebut menunjukkan keseluruhan responden memiliki sikap yang positif, kesiapan, serta dorongan untuk merubah perilaku penerapan protokol kesehatan yang tepat. Hal tersebut tidak terlepas dari pengetahuan tentang penerapan protokol kesehatan warga yang sebagian besar sudah baik. Hal itu sejalan dengan penelitian (11)yang menyatakan pengetahuan itu menumbuhkan sikap khawatir mereka pada cepatnya penyebaran virus dan dampaknya. Sikap itu mendorong mereka bertindak mengajak warga masyarakat untuk melakukan upaya pencegahan dan penanggulangan dampak pandemic.

Menurut Notoatmodjo (2010) menjelaskan bahwa terdapat enam faktor yang mempengaruhi sikap seseorang diantaranya pengalaman pribadi, pengaruh orang lain yang dianggap penting, budaya, media massa, lembaga pendidikan dan lembaga agama, serta emosional. Berdasarkan hal tersebut, media edukasi dan promosi kesehatan mengenai penerapan protokol kesehatan COVID-19 merupakan salah satu faktor yang dapat mempengaruhi sikap responden terhadap penerapan protokol kesehatan COVID-19 yang baik. Selain itu dari hasil monitoring atau turun lapangan yang dilakukan, sikap masyarakat juga dipengaruhi oleh anjuran atau himbauan yang dilakukan oleh kader, satuan tugas maupun perangkat setempat. Hal tersebut sejalan dengan penelitian (15),yang menyatakan bahwa promosi kesehatan yang dilakukan puskesmas membutuhkan peran aktif para kader kesehatan, tokoh agama, tokoh masyarakat, jaringan masyarakat sipil, organisasi masyarakat, 
dan petugas keamanan setempat. Masyarakat dapat lebih patuh pada protokol kesehatan, jika semua elemen masyarakat tersebut selalu aktif dalam mengimbau dan menerapkan protokol kesehatan di wilayahnya.

\section{Tindakan Penerapan Protokol Kesehatan COVID-19}

Tindakan penerapan protokol kesehatan COVID-19 yang baik berbanding dengan pengetahuan dan sikap warga yang juga baik. Hal tersebut juga sejalan dengan penelitian (15),yang menyatakan bahwa pemahaman dan sikap yang terbentuk dapat memengaruhi tindakan masyarakat. Selain itu, menurut penelitian(11), menyatakan bahwa pengetahuan dan sikap tentang Covid-19 di kalangan para tokoh masyarakat di Desa Jayaraga mendorong mereka untuk melakukan tindakan dalam upaya merespon pandemi. Tindakan yang dilakukan oleh para tokoh masyarakat antara lain menyebarluaskan informasi mengenai Covid-19 dan cara penyebarannya, mengkampanyekan PHBS sebagai upaya pencegahan infeksi, membantu warga kondisi sosial-ekonominya terpuruk akibat pandemi; serta memberikan aneka bentuk dukungan pada warga masyarakat.

Kemudian, masyarakat sebagian besar juga sudah menggunakan masker (terutama ketika berada di luar rumah), melakukan cuci tangan dengan sabun dan air mengalir serta melakukan jaga jarak dengan orang lain. Hal tersebut sesuai dengan anjuran WHO (2020)(16), yang menyatakan bahwa terkait usaha dalam menghadapi wabah COVID-19 adalah melakukan proteksi dasar, yang terdiri dari menggunakan masker, melakukan cuci tangan secara rutin dengan alkohol atau sabun dan air, menjaga jarak dengan seseorang yang memiliki gejala batuk atau bersin, melakukan etika batuk atau bersin, dan berobat ketika memiliki keluhan yang sesuai kategori suspek serta melaksanakan rekomendasi menjaga jarak yakni satu meter.

Beberapa tindakan penerapan protokol kesehatan COVID-19 adalah selalu memakai masker dan membuang masker bekas di tempat yang ditentukan. Dan jika merasakan sakit (ada gejala demam, flu dan batuk), maka tetap di rumah, tidak pergi bekerja, sekolah, ke pasar atau ke ruang publik untuk mencegah penularan masyarakat. Kemudian memanfaatkan fasilitas telemedicine atau sosial media kesehatan dan menghindari transportasi publik, memberitahu dokter dan perawat tentang keluhan dan gejala, serta riwayat bekerja ke daerah terjangkit atau kontak dengan pasien COVID-19. Selama di rumah, bisa melakukan pekerjaan dari rumah, menggunakan kamar terpisah dari anggota keluarga lainnya, dan menjaga jarak 1 meter dari anggota keluarga, melakukan pengecekan suhu harian, mengamati batuk dan sesak nafas, menghindari pemakaian bersama peralatan makan dan mandi serta tempat tidur, 
menerapkan perilaku hidup bersih dan sehat, serta mengkonsumsi makanan bergizi, mencuci tangan dengan sabun dan air mengalir dan melakukan etika batuk dan bersin, menjaga kebersihan dan kesehatan rumah dengan cairan desinfektan, selalu berada di ruang terbuka dan berjemur di bawah sinar matahari setiap pagi ( \pm 15-30 menit) serta menghubungi segera fasilitas pelayanan kesehatan jika sakit berlanjut seperti sesak nafas dan demam tinggi, untuk mendapatkan perawatan lebih lanjut (17).

\section{KESIMPULAN DAN SARAN}

Pengetahuan warga di wilayah program RT Siaga Kota Surabaya sebagian besar menunjukkan pengetahuan yang baik terhadap penerapan protokol kesehatan COVID-19 yakni sebanyak 99\% responden. Sikap warga di wilayah program RT Siaga Kota Surabaya keseluruhan menunjukkan sikap yang baik terhadap penerapan protokol kesehatan COVID19, yakni sebanyak $100 \%$ responden. Tindakan warga di wilayah program RT Siaga Kota Surabaya sebagian besar menunjukkan tindakan yang baik terhadap penerapan protokol kesehatan COVID-19 yakni sebanyak 97\% responden. Saran yang dapat diberikan kepada bagi masyarakat dan Perangkat Setempat antara lain Membuat kebijakan terkait penerapan protokol kesehatan di wilayah lingkungan setempat. Seperti terkait penggunaan masker, keharusan cuci tangan, menjaga jarak dan protokol kesehatan lainnya, melakukan optimalisasi perubahan kegiatan kerumunan massa secara offline menjadi online. Seperti peringatan bulan kemerdekaan dengan lomba secara online, kegiatan arisan melalui online, kegiatan pengajian online dan kegiatan lainnya, melakukan peningkatan penyediaan fasilitas penunjang protokol kesehatan yang masih belum optimal. Seperti sarana cuci tangan dengan sabun dan air mengalir di setiap rumah, membuat sistem kontrol dan monitoring dengan berbagai elemen masyarakat setempat untuk menjaga kedisiplinan penerapan protokol kesehatan dengan tepat. Bagi Instansi yakni diharapkan untuk meningkatkan wilayah program sasaran, agar semakin banyak masyarakat yang dijangkau. Bagi Peneliti yakni Perlu adanya penelitian lanjutan mengenai faktor-faktor yang mempengaruhi pengetahuan, sikap dan Tindakan masyarakat terhadap penerapan protokol kesehatan COVID-19.

\section{DAFTAR PUSTAKA}

1. Hafeez et al. A Review of COVID-19 (Coronavirus Disease-2019) Diagnosis, Treatments and Prevention. Eurasian J Med Oncol. 2020;

2. Susilo A, Rumende CM, Pitoyo CW, Santoso WD, Yulianti M, Herikurniawan H, et al. 
Coronavirus Disease 2019: Tinjauan Literatur Terkini. J Penyakit Dalam Indones. 2020;7(1):45.

3. Gugus Tugas COVID-19. Peta Sebaran Data COVID-19. https://covid19.go.id. 2020.

4. Gugus Tugas Covid-19 Jawa Timur. Peta Sebaran Data COVID-19 di Jawa Timur. http://infocovid19.jatimprov.go.id/. 2020.

5. Dinas Kesehatan Kota Surabaya. Grafik Tren dan Kumulatif Konfirmasi Per 25 Mei di Surabaya. https://lawancovid-19.surabaya.go.id/. 2020.

6. Purnamasari I, Raharyani AE. Tingkat Pengetahuan dan Perilaku Masyarakat Kabupaten Wonosobo Tentang Covid-19. J Ilm Kesehat. 2020;(Mei):33-42.

7. Yanti NPED, Nugrah ADP, Wisnawa GA, Agustina NPD, Diantari NPA. Gambaran pengetahuan masyarakat tentang covid-19 dan perilaku masyarakat di masa pandemi covid-19. J Keperawatan Jiwa. 2020;8(3):491-504.

8. Sari DP, Sholihah N, Atiqoh. Hubungan antara pengetahuan masyarakat dengan kepatuhan penggunakan masker sebagai upaya pencegahan penyakit COVID-19 di Ngronggah. INFOKES J. 2020;10(1):52-5.

9. Notoatmodjo S. Promosi Kesehatan dan Perilaku Kesehatan. Jakarta: PT. Rineka Cipta; 2012.

10. Wiranti, Sriatmi A, Kusumastuti W. Determinan kepatuhan masyarakat Kota Depok terhadap kebijakan pembatasan sosial berskala besar dalam pencegahan COVID-19. J Kebijak Kesehat Indones. 2020;

11. Rosidin U, Rahayuwati L, Herawati E. Perilaku dan Peran Tokoh Masyarakat dalam Pencegahan dan Penanggulangan Pandemi Covid -19 di Desa Jayaraga, Kabupaten Garut. Umbara. 2020;

12. Sulistyaningtyas T, Jaelani J, Suryani Y. Informasi Wabah Virus Covid-19: Kuasa Pengetahuan dan Kelas Sosial. 2020.

13. Sukesih, Usman, Budi S, Nur Adkhana Sari D. Pengetahuan Dan Sikap Mahasiswa Kesehatan Tentang Pencegahan Covid-19 Di Indonesia. J Ilmu Keperawatan dan Kebidanan. 2020;11(2):410-4.

14. Notoatmodjo S. Ilmu Perilaku Kesehatan. Jakarta: PT. Rineka Cipta; 2010.

15. Yuningsih R. Promosi Kesehatan Pada Kehidupan New Normal Pandemi Covid-19. Info Singk. 2020;

16. WHO. 2020. Infection prevention and control during health care when novel coronavirus ( $\mathrm{nCoV}$ ) infection is suspected: interim guidance $\mathrm{J} 2020 \mathrm{U}$ https://tinyurl. com/r7w9ke. (accessed 2020-05-29). Infection prevention and control during health care when COVID-19 is suspected. Who. 2020;

17. Kemendagri. Pedoman Umum Kesiapsiagaan Menghadapi Penyakit Coronavirus (2019nCoV) untuk Pemerintah Daerah. Gugus Tugas Percepatan Penanganan COVID-19. 2020; 